\title{
Tagging and Recapture of Atlantic Halibut (Hippoglossus hippoglossus L.) on the Continental Shelves off Eastern Canada, and off Western and Eastern Greenland
}

\author{
Olav Rune God $\emptyset^{1}$ \\ Directorate of Fisheries, Institute of Marine Research, \\ P. O. Box 1870, N-5011 Bergen-Nordnes, Norway \\ and \\ Tore Haug ${ }^{1}$ \\ Department of Marine Biology, Troms $\varnothing$ Museum, University of Troms $\varnothing$, \\ P. O. Box 2550, N-9001 Troms $\varnothing$, Norway
}

\begin{abstract}
Earlier investigations on Atlantic halibut, (Hippoglossus hippoglossus L.), mostly from the eastern Atlantic Ocean, have shown that it is a migratory species with potential of mixing between stocks. This paper presents data from Norwegian tagging experiments carried out in the Newfoundland/Labrador region and off the western and eastern coasts of Greenland in 1955-69, where 111,230 and 796 fish respectively were tagged. The recapture frequencies were $3.6 \%, 11.7 \%$ and $16.0 \%$, respectively, with most of the recaptures in the area of release. Considerable movements within each of the two main Greenland areas were observed, however, there was no dominant migration direction. This is in accordance with observations from other areas. Some movement of fish between the three regions was recorded, and two fish tagged off eastern Greenland were recaptured in Icelandic waters.
\end{abstract}

\section{Introduction}

The Atlantic halibut, (Hippoglossus hippoglossus L.), is common throughout the North Atlantic Ocean on both the North American and European coasts. It has been confirmed through several tagging studies that the species is, at least in certain parts of its life cycle, highly migratory and has a considerable potential for mixing between stocks (God $\varnothing$ and Haug, 1988).

There is very little published information concerning halibut biology from the Northwest Atlantic Ocean (Bowering, 1986). Tagging experiments have been performed in the Gulf of St. Lawrence and the Nova Scotian shelf from 1946 to 1973 (Martin and McCracken, 1950; McCracken and Martin, 1955; McCracken, 1958; Wise and Jensen, 1959; Jensen and Wise, 1961; Kohler, 1964; Stobo et al., 1988), but there is no migration data available from further north along the Canadian coast, north of the Grand Banks off Newfoundland, or from the west and east coasts of Greenland. During 1955-69 annual research cruises to these areas to tag halibut were sponsored by the Directorate of Fisheries, Bergen, Norway.

Preliminary results of some of the recaptures made from western Greenland 1958, 1959 and 1961 taggings were presented by Kvavig (1972a, b). These papers analyze all the recapture results from the Norwegian taggings off the eastern coast of Canada in 1955, 1957 and 1958, off western Greenland in 1955-69 and off eastern Greenland in 1959 and 1961-65.

\section{Materials and Methods}

All fish tagged were caught during research fisheries using longlines. Hydrostatic LEA tags (Anon., 1953) were attached to the eye side operculum of each fish considered capable of surviving. Total lengths were measured in most fish, but sexing fish was impossible due to the morphological similarities of males and females.

Fish were tagged in Canadian shelf areas at five different sites (Table 1, Fig. 1). On the west coast of Greenland fish were tagged on banks of the shallow and relatively narrow continental shelf, which runs in a south-north direction along the coastline (Table 2, Fig. 2). Fish tagged and recaptured within the same geographic boundaries given in Table 2 are defined as recaptured in the tagging area. All others are classified as long distance migrants. On the east coast of Greenland fish were tagged at 13 sites (Table 3, Fig. 3). There are

Authorship equal 
TABLE 1. Positions of tagging areas on the banks off Newfoundland and along the shelf on the east coast of Labrador (see Fig. 1).

\begin{tabular}{lc}
\hline \multicolumn{1}{c}{ Tagging area } & Geographic position \\
\hline A. Flemish Cap, Newfoundland & $45^{\circ} 25^{\prime} \mathrm{W}-45^{\circ} 45^{\prime} \mathrm{W} ; 46^{\circ} 25^{\prime} \mathrm{N}-46^{\circ} 40^{\prime} \mathrm{N}$ \\
B. West of Newfoundland & $50^{\circ} 40^{\prime} \mathrm{W}-50^{\circ} 45^{\prime} \mathrm{W} ; 49^{\circ} 00^{\prime} \mathrm{N}-49^{\circ} 05^{\prime} \mathrm{N}$ \\
C. Okak/Nain Bank, Labrador & $57^{\circ} 30^{\prime} \mathrm{N}-58^{\circ} 25^{\prime} \mathrm{N}$ \\
D. Saglek Bank, Labrador & $58^{\circ} 25^{\prime} \mathrm{N}-60^{\circ} 30^{\prime} \mathrm{N}$ \\
E. East of Baffin Island, Labrador & $63^{\circ} 10^{\prime} \mathrm{N}-63^{\circ} 15^{\prime} \mathrm{N}$ \\
\hline
\end{tabular}

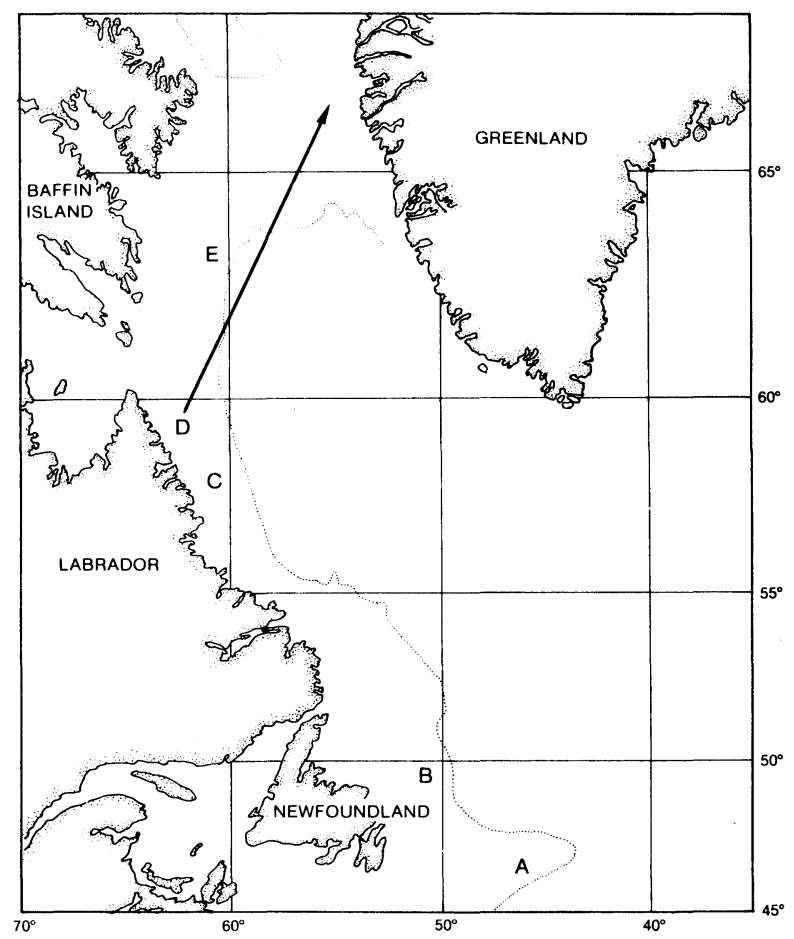

Fig. 1. Tagging sites (capital letters, see Table 1) and recapture sites (indicated by arrow) of Atlantic halibut caught off eastern Canada.

no distinct banks on the eastern Greenland continental shelf as on the west side of the island, so the fish were classified as long distance migrants when recaptured outside the tag release area. Each recapture made on the eastern Greenland shelf was allocated to the nearest tagging site.

More detailed information of all recaptures along with a preliminary report of these tagging experiments was presented during the 1987 NAFO Special Session on Deepwater Fishes (God $\varnothing$ and Haug, MS 1987).

\section{Results}

\section{Length distribution}

The fish tagged on the Canadian shelf area ranged in size between $60-145 \mathrm{~cm}$ (Fig. 4). In western and eastern Greenland waters the tagged fish were gener- ally smaller (range $50-125 \mathrm{~cm}$ ), most being less than $100 \mathrm{~cm}$.

\section{Tagging and recaptures off Canada}

A total of 111 halibut ( 35 at site $A, 22$ at site $B, 7$ at site $C, 29$ at site $D$, and 18 at site $E$ in Fig. 1) were tagged and released at the sites off the east coast of Canada in 1955, 1957 and 1958. Of these, 4 (3.6\%) were recaptured. Three were recaptured in the same areas where they were tagged (sites $A, B$ and $E$ in Fig. 1), while one long distance migrant had moved from Saglek Bank (site $D$ in Fig. 1) northwest to the west coast of Greenland.

\section{Tagging and recaptures off western Greenland}

In the 11 tagging sites to the west of Greenland 796 halibut were tagged in 1955-69 (Table 4). Of these, 93 $(11.7 \%)$ were recaptured, ranging from a few days up to 5 years after release.

Of the recaptures, $40(43.0 \%)$ were made in the tagging areas (Table 4), while 49 long distance migrants were recaptured either at other sites on the western Greenland shelf (43) or outside this shelf (6). The remaining 4 were insufficiently documented to determine distance moved. Of the 6 caught outside the western Greenland shelf, 5 were recaptured in Newfoundland bank areas and one at the GreenlandIceland ridge west of Iceland (Fig. 2). On the western Greenland shelf, 25 long distance migrants had moved northwards, 8 had moved southwards, while 10 of the fish tagged west of the Tovqussaq Bank had moved eastwards on the bank (Table 4, Fig. 2).

\section{Tagging and recaptures off eastern Greenland}

Of the 230 halibut tagged at 13 sites off the east coast of Greenland in 1959 and 1961-65, 37 (16.0\%) were recaptured, from a few days up to 8 years after tagging (Table 5). Thirteen (35.1\%) were recaptured in the tagging areas. Of the other recaptures on the eastern Greenland shelf, 11 had moved southwards and 10 northwards (Table 5, Fig. 3). Those leaving the eastern Greenland areas included one which had moved eastwards to the coastal waters of Iceland and two which were recaptured on the continental shelf on the west side of Greenland.

\section{Discussion}

A comparison of the size of the fish in the present study (Fig. 4) with other data from the western and eastern North Atlantic (McCracken, 1958; Bowering, 1986; Mathisen and Olsen, 1968; Haug and Tjemsland, 1986; Jakupsstovu and Haug, 1988) shows that the present material is a mixture of many medium sized immature fish, and a few larger mature specimens, with 
the latter observed particularly along the Canadian coast. The absence of small immature fish and the low number of large adult fish suggest that the continental shelf areas off eastern Canada and around Greenland are general feeding areas rather than typical nursery or spawning areas.

Tagging experiments on halibut in Norwegian waters, using Danish seines and gill nets, clearly revealed the existence of both nursery and spawning areas. Young immature fish in the nursery areas do not move away from the areas during their first 4-6 years,

TABLE 2. Position of tagging areas along the continental shelf on the west coast of Greenland (see Fig. 2).

\begin{tabular}{lc}
\hline \multicolumn{1}{c}{ Tagging area } & Geographic position \\
\hline A. Julianehaabbugt & $\mathrm{S}$ of $61^{\circ} \mathrm{N}$ \\
B. Navnløse Bank & $61^{\circ} 00^{\prime} \mathrm{N}-61^{\circ} 57^{\prime} \mathrm{N}$ \\
C. Fredrikshaab Bank & $61^{\circ} 57^{\prime} \mathrm{N}-62^{\circ} 27^{\prime} \mathrm{N}$ \\
D. Danas Bank & $62^{\circ} 27^{\prime} \mathrm{N}-63^{\circ} 00^{\prime} \mathrm{N}$ \\
E. Fiskenaes Bank & $63^{\circ} 00^{\prime} \mathrm{N}-63^{\circ} 30^{\prime} \mathrm{N}$ \\
F. Fyllas Bank & $63^{\circ} 30^{\prime} \mathrm{N}-64^{\circ} 15^{\prime} \mathrm{N}$ \\
G. Tovqussaq Bank & $\mathrm{E}$ of $54^{\circ} 40^{\prime} \mathrm{W} ; 64^{\circ} 15^{\prime} \mathrm{N}-64^{\circ} 40^{\prime} \mathrm{N}$ \\
H. West of Tovqussaq Bank & W of $54^{\circ} 40^{\prime} \mathrm{W} ; 64^{\circ} 10^{\prime} \mathrm{N}-65^{\circ} 00^{\prime} \mathrm{N}$ \\
I. Sukkertop Bank & $\mathrm{E}$ of $54^{\circ} 40^{\prime} \mathrm{W} ; 64^{\circ} 50^{\prime} \mathrm{N}-65^{\circ} 20^{\prime} \mathrm{N}$ \\
K. North of Lille Hellefisk Bank & $66^{\circ} 00^{\prime} \mathrm{N}-66^{\circ} 30^{\prime} \mathrm{N}$ \\
L. North of Store Hellefisk Bank & $68^{\circ} 00^{\prime} \mathrm{N}-68^{\circ} 30^{\prime} \mathrm{N}$ \\
\hline
\end{tabular}

whereas in the spawning areas, adult fish gather only once a year during the spawning season (God $\varnothing$ and Haug, 1988). Rearing areas for juvenile fish, and spawning areas from which the adults make annual dispersal and return migrations, have also been reported from Canadian waters south of Newfoundland (Stobo et al., 1988). In the western Atlantic north of the Grand Banks of Newfoundland, however, the only documented halibut nursery area is, to our knowledge, the shallow shelf areas (Faxa Bay) on the west side of Iceland (Sigurdsson and Fridriksson, 1952; Sigurdsson, 1956). Icelandic tagging experiments revealed migrations from the Faxa Bay nursery areas to eastern and western Greenland shelf areas as well as to the banks off Newfoundland (Jonsson, 1976). No definite spawning grounds have been documented in the western Atlantic north of Newfoundland, but the occurrence of pelagic eggs and larvae suggests that the species breeds in deep waters on the slope of the continental shelf off western Greenland (Jensen, 1926) and southwest of Iceland (McIntyre, 1958).

The present tagging experiments clearly showed that most fish remained in the main shelf areas where they were tagged. However, extensive migrations also occurred in several directions, in many cases over considerable distances along the coastlines within each

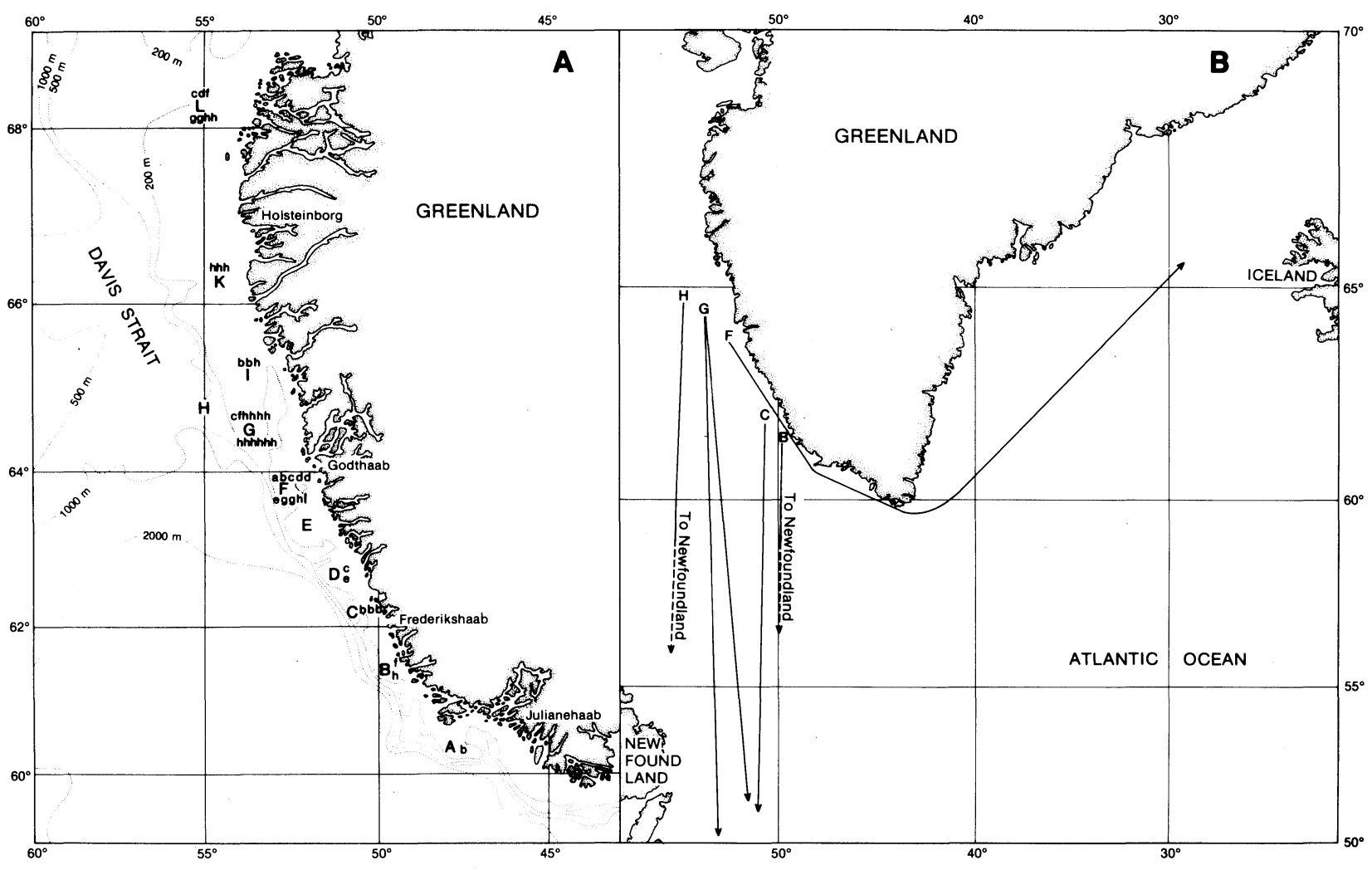

Fig. 2. Detailed map (A) of tagging sites of Atlantic halibut on the west coast of Greenland (capital letters, see Table 2) and recapture sites (small letters; recapture 'a' was tagged at site A, recapture ' $b$ ' was tagged at site B, etc.) in western Greenland shelf areas; and (B) shows the movement of long distance migrants (arrows) which left the western Greenland shelf area 
TABLE 3. Position of tagging areas along the coast of eastern Greenland (see Fig. 3).

\begin{tabular}{lc}
\hline \hline \multicolumn{1}{c}{ Tagging area } & Geographic position \\
\hline A. East of Kap Farvel & $59^{\circ} 54^{\prime} \mathrm{N}, 42^{\circ} 33^{\prime} \mathrm{W}$ \\
B. East of Kap Walløe & $60^{\circ} 39^{\prime} \mathrm{N}, 42^{\circ} 07^{\prime} \mathrm{W}$ \\
C. East of Kap Steen Bille & $62^{\circ} 04^{\prime} \mathrm{N}, 40^{\circ} 40^{\prime} \mathrm{W}-41^{\circ} 00^{\prime} \mathrm{W}$ \\
D. Southeast of Kap Skold & $62^{\circ} 43^{\prime} \mathrm{N}, 40^{\circ} 56^{\prime} \mathrm{W}$ \\
E. Northeast of Kap Skold & $63^{\circ} 13^{\prime} \mathrm{N}, 40^{\circ} 48^{\prime} \mathrm{W}$ \\
F. East of Kap Moltke & $63^{\circ} 29^{\prime} \mathrm{N}, 39^{\circ} 18^{\prime} \mathrm{W}$ \\
G. East of Kap Møsting & $63^{\circ} 30^{\prime} \mathrm{N}-63^{\circ} 55^{\prime} \mathrm{N} ; 37^{\circ} 50^{\prime} \mathrm{W}-38^{\circ} 30^{\prime} \mathrm{W}$ \\
H. Northeast of Kap Møsting & $63^{\circ} 58^{\prime} \mathrm{N}, 39^{\circ} 32^{\prime} \mathrm{W}$ \\
I. Southeast of Kap Loven $\varnothing \mathrm{rn}$ & $63^{\circ} 58^{\prime} \mathrm{N}-64^{\circ} 10^{\prime} \mathrm{N} ; 35^{\circ} 20^{\prime} \mathrm{W}-36^{\circ} 20^{\prime} \mathrm{W}$ \\
K. East of Kap Loven $\varnothing r n$ & $64^{\circ} 18^{\prime} \mathrm{N}, 39^{\circ} 55^{\prime} \mathrm{W}$ \\
L. Northeast of Kap Loven $\varnothing \mathrm{rn}$ & $64^{\circ} 45^{\prime} \mathrm{N}, 35^{\circ} 14^{\prime} \mathrm{W}$ \\
M. Kap Dan Bank & $64^{\circ} 50^{\prime} \mathrm{N}-65^{\circ} 28^{\prime} \mathrm{N} ; 34^{\circ} 00^{\prime} \mathrm{W}-38^{\circ} 00^{\prime} \mathrm{W}$ \\
N. Southeast of Kap Nordenskiold & $65^{\circ} 35^{\prime} \mathrm{N}-60^{\circ} 02^{\prime} \mathrm{N} ; 31^{\circ} 54^{\prime} \mathrm{W}-33^{\circ} 30^{\prime} \mathrm{W}$ \\
\hline
\end{tabular}

area. Such dispersive ability of medium sized immature halibut have been observed in Norwegian waters (God $\varnothing$ and Haug, 1988) and also in Canadian waters south of Newfoundland (Stobo et al., 1988). The more extreme long distance migrations of some specimens, e.g., from western Greenland to Newfoundland which include potential crossings of deepwater areas, emphasizes the large migration potential possessed by the species. Similar and even longer migrations were observed in Norwegian (Devold, 1943; God $\varnothing$ and Haug, 1988), Faroese (Vedel-Tåning, 1938, 1947), Icelandic (Jonsson, 1978; Bowering, 1986), and North American waters south of Newfoundland (McCracken and Martin, 1955; Jensen and Wise, 1961).

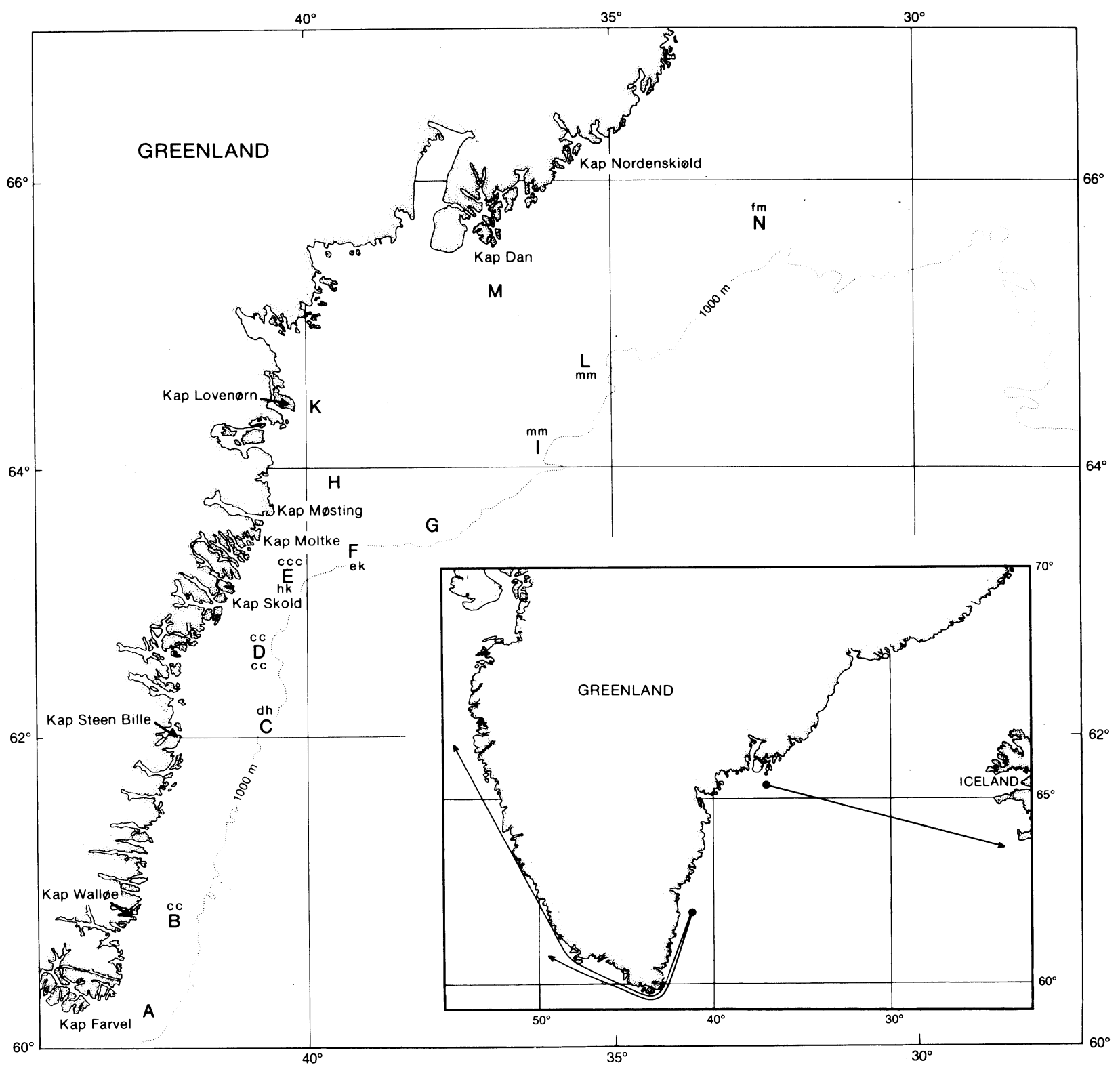

Fig. 3. Map showing the tagging sites of Atlantic halibut along the coast of eastern Greenland (capital letters, see Table 3 ), and recapture sites ( small letters; recapture ' $c$ ' was tagged in site $C$, recapture ' $d$ ' was tagged in site $D$, etc.) in eastern Greenland shelf areas. The insert map shows the movement of long distance migrants (arrows) from the eastern Greenland shelf area. 
The validity of using tag return results to analyze migration patterns of fish is dependent upon the distribution of fishing effort. In this case there was no directed fishery for halibut in the main experimental
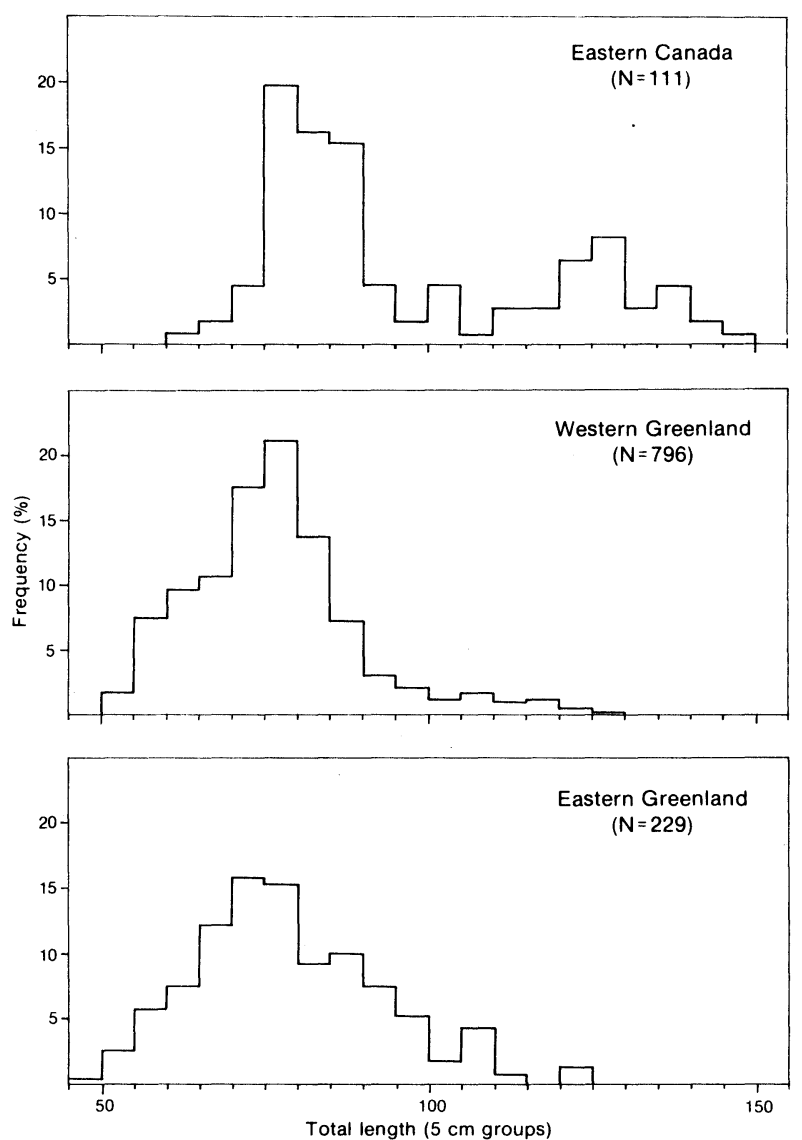

Fig. 4. Length composition of Atlantic halibut caught by longlines and tagged off eastern Canada and off western and eastern Greenland ( $\mathrm{N}=$ number of fish). area (Greenland) during the period, and returns are the outcome of halibut caught incidentally in other fisheries. According to statistics (ICNAF 1951-78; NAFO 1979-85) the majority of the halibut catches in Greenland waters in the 1960s were taken by trawlers from the Federal Republic of Germany and longliners from Norway in fisheries directed mainly towards cod, (Gadus morhua). Normally these fisheries are assumed to cover the main area of distribution of halibut. However, the Greenland cod fishery is characterized by dramatic changes in recruitment and production (Harden Jones, 1968). Taking this into account and further, keeping in mind the wide geographic distribution of halibut, all size groups of halibut cannot be expected to be covered by the same amount of effort, not even one size group in one area through a period of years. For these reasons a more quantitative interpretation of the data was not feasible.

The patterns of apparent random directional and often very long migrations of the medium sized immature halibut led God $\varnothing$ and Haug (1988) to doubt that these fish could have navigated according to current stimuli. Several other possible orientation mechanisms are generally observed in fish, for example inertial migrations (Harden Jones, 1984) or geomagnetic and geoelectric orientation (Quinn, 1984; Walker, 1984). The present material gives no opportunity, however, to elucidate possible migration mechanisms for halibut.

Because of the lack of tagging data from halibut spawning areas in the western Atlantic north of Newfoundland, it is unknown whether these fish are able to return to the same spawning area for repeated spawning as has been observed for halibut on the Nova Scotian shelf in Canada (Stobo et al., 1988) as well as in the eastern Atlantic (God $\varnothing$ and Haug, 1988).

TABLE 4. Tagging areas, number of fish tagged, number and area of recapture of Atlantic halibut tagged along the continental shelf west of southern Greenland during 1955-69.

\begin{tabular}{|c|c|c|c|c|c|c|c|c|c|c|c|c|c|c|}
\hline \multirow[b]{2}{*}{$\begin{array}{c}\text { Tagging areas } \\
\text { (No. of fish tagged in parentheses) }\end{array}$} & \multicolumn{14}{|c|}{ Number and area of recapture } \\
\hline & A & B & C & D & E & $\mathbf{F}$ & G & $H$ & 1 & K & L & $\begin{array}{c}\text { Total } \\
\text { West } \\
\text { Greenland } \\
\text { shelf }\end{array}$ & $\begin{array}{l}\text { Outside } \\
\text { West } \\
\text { Greenland } \\
\text { shelf }\end{array}$ & $\begin{array}{l}\text { Without } \\
\text { recapture } \\
\text { position }\end{array}$ \\
\hline A. Julianehaabbugt (177) & 12 & & & & & 1 & & & & & & 13 & & 1 \\
\hline B. Navnløse Bank (93) & 1 & 6 & 3 & & & 1 & & & 2 & & & 13 & 1 & \\
\hline C. Fredrikshaab Bank (53) & & & 6 & 1 & & 1 & & & & & 1 & 10 & 1 & \\
\hline D. Danas Bank (24) & & & & 2 & & 2 & & & & & 1 & 5 & & \\
\hline E. Fiskenaes Bank (35) & & & & 1 & 3 & 1 & & & & & & 5 & & \\
\hline F. Fyllas Bank (28) & & 1 & & & & 4 & 1 & & & & 1 & 7 & 1 & \\
\hline G. Tovqussaq Bank & & & & & & 2 & 1 & & & & 2 & 5 & 2 & 2 \\
\hline H. West of Tovqussaq Bank (243) & & 1 & & & & 1 & 10 & 3 & 1 & 3 & 2 & 21 & 1 & 1 \\
\hline I. Sukkertop Bank (16) & & & & & & & & & 2 & & & 2 & & \\
\hline K. North of Lille Hellefisk Bank (7) & & . & & & & & & & & & & & & \\
\hline L. North of Store Hellefisk Bank (11) & & & & & & 1 & & & & & 1 & 2 & & \\
\hline
\end{tabular}


TABLE 5. Tagging area, number of fish tagged, number and area of recapture of Atlantic halibut tagged along the continental shelf east of southern Greenland during 1959-65.

\begin{tabular}{|c|c|c|c|c|c|c|c|c|c|c|c|c|c|c|}
\hline \multirow[b]{2}{*}{$\begin{array}{c}\text { Tagging areas } \\
\text { (No. of fish tagged in parentheses) }\end{array}$} & \multicolumn{14}{|c|}{ Number and area of recapture } \\
\hline & A & $\mathrm{B}$ & $\mathrm{C}$ & $\mathrm{D}$ & $E$ & $\mathrm{~F}$ & G & $\mathrm{H}$ & $\mathrm{l} K$ & $\mathrm{~L}$ & M & $\mathrm{N}$ & $\begin{array}{c}\text { Total } \\
\text { East } \\
\text { Greenland } \\
\text { shelf }\end{array}$ & $\begin{array}{c}\text { Outside } \\
\text { East } \\
\text { Greenland } \\
\text { shelf }\end{array}$ \\
\hline \multicolumn{15}{|l|}{ A. East of Kap Farvel (9) } \\
\hline C. East of Kap Steen Bille (23) & & 2 & 4 & 4 & 3 & & & & & & & & 13 & 2 \\
\hline D. Southeast of Kap Skold (14) & & & 1 & 2 & & & & & & & & & 3 & \\
\hline E. Northeast of Kap Skold (56) & & & & & & 1 & & & & & & & 1 & \\
\hline F. East of Kap Moltke (3) & & & & & & 2 & & & & & & 1 & 3 & \\
\hline G. East of Kap Møsting (21) & & & & & & & & & & & & & & \\
\hline H. Northeast of Kap Møsting (2) & & & 1 & & 1 & & & & & & & & 2 & \\
\hline I. Southeast of Kap Loven $\phi r n(8)$ & & & & & & & & & & & & & & \\
\hline K. East of Kap Loven $\phi \mathrm{rn}(10)$ & & & & & 1 & 1 & & & & & & & 2 & \\
\hline L. Northeast of Kap Loven $\phi r n$ (5) & & & & & & & & & & 1 & & & 1 & \\
\hline M. Kap Dan Bank (71) & & & & & & & & & 2 & 2 & 3 & 1 & 8 & 1 \\
\hline N. Southeast of Kap Nordenskiold (5) & & & & & & & & & & & & 1 & 1 & \\
\hline
\end{tabular}

\section{Acknowledgements}

We thank the scientists and field assistants from the Directorate of Fisheries, Bergen, Norway, who tagged halibut during research cruises with R/V G. $O$. Sars in the western North Atlantic in 1955-69. Furthermore we express our gratitude to M. S. Nilsen, G. W. Pettersen, and $\mathrm{Aa}$. Svendsen for technical assistance, and to R. T. Barrett for criticism of the manscript and correction of the English text. Financial support was received from the Norwegian Council of Fisheries Research (NFFR), project No. I 405.003.

\section{References}

ANON. 1953. A guide to fish marks. ICES J. Cons., 19: 241289.

BOWERING, W. R. 1986. The distribution, age and growth and sexual maturity of Atlantic halibut (Hippoglossus hippoglossus) in the Newfoundland and Labrador area of the Northwest Atlantic. Can. Tech. Rep. Fish. Aquat. Sci., 1432: IV+34 $\mathrm{p}$.

DEVOLD, F. 1943. Notes on halibut (Hippoglossus vulgaris) (Fleming). ICES Ann. Biol., 1: 35-40.

GODO, O. R., and T. HAUG. MS 1987. Tagging and recaptures of Atlantic halibut (Hippoglossus hippoglossus L.) on the continental shelves off eastern Canada and off western and eastern Greenland. NAFO SCR Doc., No. 82, Serial No. N1385, $23 \mathrm{p}$.

1988. Tagging and recapture of Atlantic halibut, Hippoglossus hippoglossus, in Norwegian waters. ICES J. Cons., 44: 169-179.

HARDEN JONES, F. R. 1968. Fish Migrations. Edward Arnold (Publishers) Ltd., London. 325 p.

1984. Could fish use inertial clues when on migration? In Mechanisms of migration in fishes, J. D. McCleave, G. P. Arnold, J. J. Dodson, and W. H. Neill (eds), NATO Conference Series, Series IV: Marine Science, Vol. 14, Plenum Press, New York and London, p. 67-78.
HAUG, T., and J. TJEMSLAND. 1986. Changes in size- and age distributions and age at sexual maturity in Atlantic halibut, Hippoglossus hippoglossus, caught in North Norwegian waters. Fish. Res., 4: 145-155.

ICNAF. 1951-78. Fishery Statistics. ICNAF Stat. Bull., vols. 1-28.

JAKUPSSTOVU, S. H. I., and T. HAUG. 1988. Growth, sexual maturation, and spawning season of Atlantic halibut, Hippoglossus hippoglossus, in Faroese waters. Fish. Res., 6: 201-215.

JENSEN, A. C., and J. P. WISE. 1961. Movements of tagged halibut off New England. Trans. Amer. Fish. Soc., 90: 489-490.

JENSEN, A. S. 1926. Investigations of the Dana in west Greenland waters, 1925. ICES Rapp. Proc.-Verb., 38: 85-102.

JONSSON, G. 1978. Merkingar a ludu. Sjavarfrettir, 6: 26-28.

KOHLER, A. C. 1964. Movements of halibut on the Nova Scotian and Grand Banks. J. Fish. Res. Board Can., 21: 837840.

KVAVIG, P. 1972a. Kveitemerking i Davidsstredet i 1958. Fisk. Gang, 58: 56-57.

1972b. Kveitemerking i Davisstredet i 1959 og 1961. Fisk. Gang, 58: 332-333.

MARTIN, W. R., and F. D. McCRACKEN. 1950. Movements of halibut on the Canadian Atlantic coast. Fish. Res. Board Can., Atl. Prog. Rep., 50: 3-8.

MATHISEN, O. A., and S. OLSEN. 1968. Yield isopleths of the halibut, Hippoglossus hippoglossus, in Northern Norway. Fiskeridir. Skr. (Havunders), 14: 129-159.

MCCRACKEN, F. D. 1958. On the biology and fishery of the Canadian Atlantic halibut, Hippoglossus hippoglossus L., J. Fish. Res. Board Can., 15: 1269-1311.

MCCRACKEN, F. D., and W. R. MARTIN. 1955. Recent recoveries of tagged halibut. Fish. Res. Board Can., Atl. Prog. Rep., 61: 4.

MCINTYRE, A. D. 1958. Scottish halibut investigations. ICES Ann. Biol., 14: 31-33.

NAFO. 1979-85. Fishery Statistics. NAFO Stat. Bull., vols. 29-35.

QUINN, T.P. 1984. An experimental approach to fish compass and map orientation. In: Mechanisms of migration in fishes, J. D. McCleave, G. P. Arnold, J. J. Dobson and W. 
H. Neill (eds), NATO Conference Series, Series IV: Marine Sciences, Vol. 14, Plenum Press, New York and London, p. 113-124.

SIGURDSSON, A. 1956. Contribution to the life history of the halibut at the West of Iceland in recent years (1936-1950). Medd. Dan. Fisk.-Havunders., N.S., 1(16): 1-24.

SIGURDSSON, A., and A. FRIDRIKSSON. 1952. On the Icelandic fishery in the Denmark Strait in 1950. ICES Ann. Biol., 8: 45-46.

STOBO, W. T., J. D. NEILSON, and P. G. SIMPSON. 1988 Movement of Atlantic halibut (Hippoglossus hippoglossus) in the Canadian North Atlantic. Can. J. Fish. Aquat. Sci., 45(3): 484-491.
VEDEL-TÅNING, A. 1938. Migrations of small halibut marked in Faroese waters. ICES J. Cons., 13: 370-375.

1947. Marking experiments on 3-5-year-old halibut in Faroese waters. ICES Ann. Biol., 2: 24.

WALKER, M. M. 1984. Magnetic sensitivity and its possible physical basis in the yellowfin tuna, Thunnus albacares. In: Mechanisms of migration in fishes, G. P. Arnold, J. J. Dobson \& W. H. Neill (eds), NATO Conference Series, Series IV: Marine Sciences, Vol. 14, Plenum Press, New York and London, p. 125-142.

WISE, J. P., and A. C. JENSEN. 1959. Movement of tagged halibut off New England. Trans. Amer. Fish. Soc., 88: 357-358. 
